\title{
Tetrabutylammonium tribromide: an effective green reagent for the one-pot reaction of 3-acetyl-2H-chromen-2-ones with o-phenylenediamines
}

\author{
Kotthireddy Kavitha,* Devulapally Srikrishna, Pramod Kumar Dubey, and Pasula Aparna \\ Department of Chemistry, Jawaharlal Nehru Technological University Hyderabad College of Engineering, \\ Kukatpally, Hyderabad, Telangana - 500 085, India \\ Email : kavithakothireddy@gmail.com
}

Received 06-09-2018

Accepted 08-21-2018

Published on line 09-21-2019

\section{Abstract}

An efficient and completely greener approach has been outlined for the reaction of 3-acetyl-2H-chromen-2ones with o-phenylenediamines using tetrabutylammonium tribromide (TBATB) to obtain 3-(quinoxalin-2-yl)$2 \mathrm{H}$-chromen-2-ones in one-pot. Alternatively, a step-wise method has also been demonstrated for the synthesis of 3-(quinoxalin-2-yl)-2H-chromen-2-ones, where 3-acetyl-2H-chromen-2-ones has first treated with TBATB to give 3-(2-bromoacetyl)-2H-chromen-2-one followed by its nucleophilic substitution reaction with ophenylenediamines. Use of polyethylene glycol-600 (PEG-600) as the solvent media, mild reaction conditions and easy isolation procedure of products are the added advantages for this synthesis. Both the one-pot and step-wise methods have been compared in terms of their reaction yields and one-pot synthesis was found to be superior. All the synthesized compounds were confirmed by characterization with ${ }^{1} \mathrm{HNMR},{ }^{13} \mathrm{CNMR}, \mathrm{HRMS}$, IR spectroscopy.

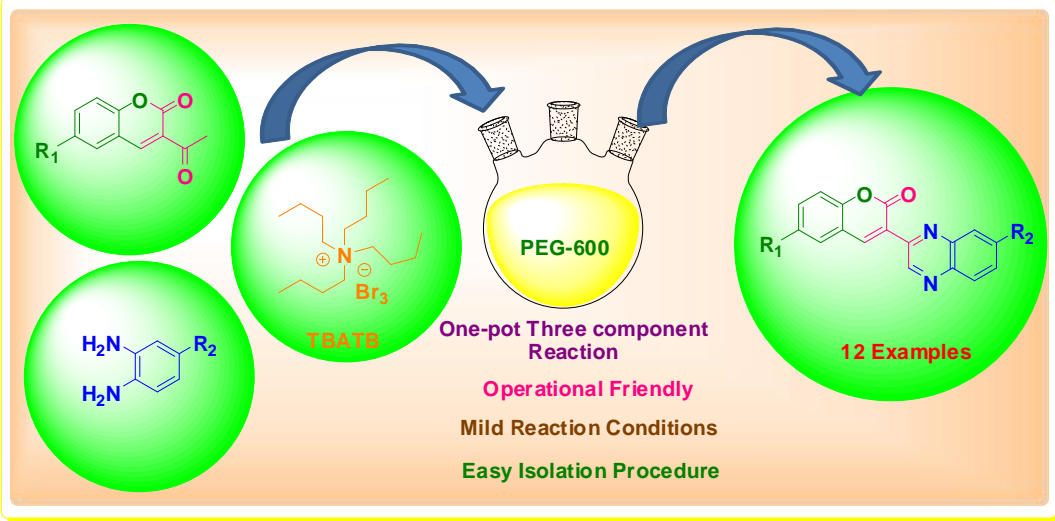

Keywords: Tetrabutylammonium tribromide, polyethylene glycol, one-pot method, coumarins, quinoxalines, green protocol 


\section{Introduction}

In the large family of heterocyclic chemistry, coumarin and its derivatives have significant role due to their distinct applications, abundant availability in nature and various routes for its synthesis. Coumarin is the effective pharmacophore with wide variety of pharmacological applications. ${ }^{1,2}$ Some of their important biological activities include cardiovascular, ${ }^{3}$ antibiotic, ${ }^{4}$ anti-viral, ${ }^{5}$ anti-depressant, ${ }^{6}$ anti-inflammatory, ${ }^{7}$ antioxidant, ${ }^{8}$ antimicrobial, ${ }^{9}$ etc. Based on their importance and widespread activities, we have recently reviewed few of the applications of coumarin and its hybrid compounds pertaining to their medicinal chemistry, material chemistry and agrochemical field. ${ }^{10}$ Some of the coumarin based drug candidates have listed below (Figure 1).

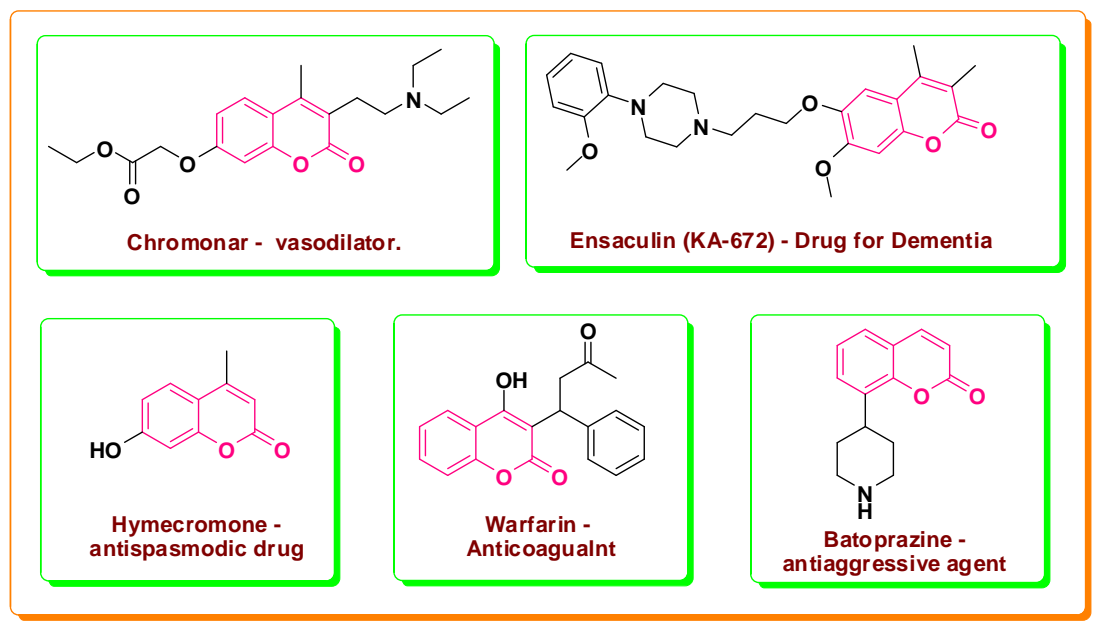

Figure 1. Commercially available coumarin based drugs.

Furthermore, quinoxalines and its derivatives have been found to exhibit diversified pharmacological activities such as anti-inflammatory, ${ }^{11}$ anti-mycobacterial, ${ }^{12}$ anti-leishmanial, ${ }^{13}$ anti-microbial, ${ }^{14}$ anti-cancer, ${ }^{15}$ anti-tubercular, ${ }^{16}$ anti-malarial, ${ }^{17}$ antibiotic, ${ }^{18}$ anti-infective, ${ }^{19}$ etc. Apart from these, quinoxaline derivatives also exhibited applications such as DNA photo cleaving reagents ${ }^{20}$ and as dyes. ${ }^{21,22}$ Some of the commercially available quinoxaline based drugs have listed in Figure 2.

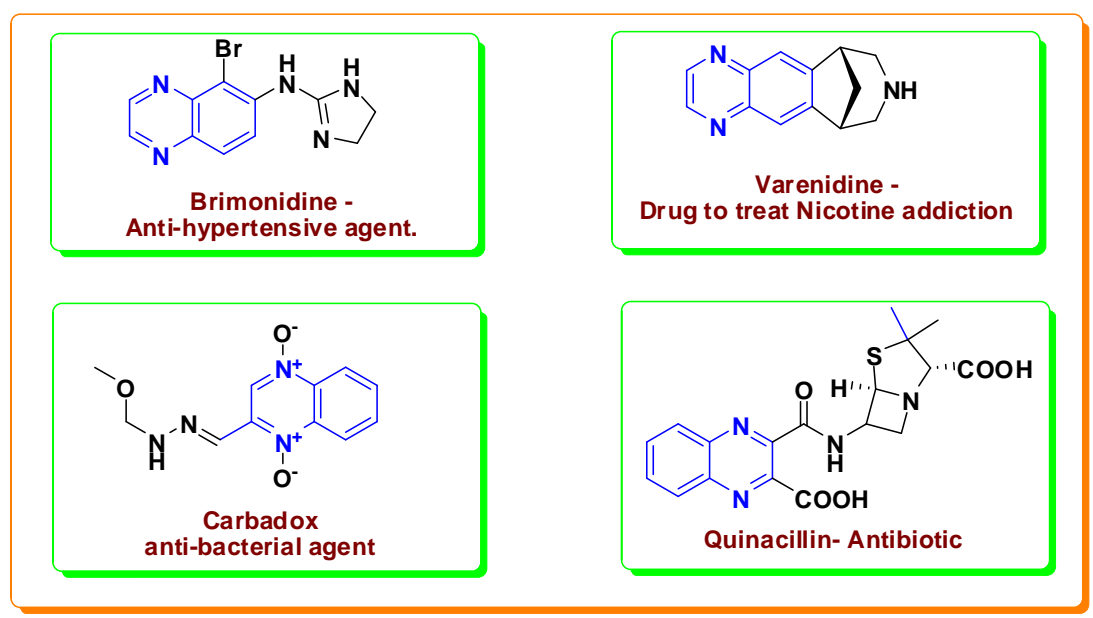

Figure 2. Commercially available quinoxaline based drugs. 
In the view of importance of coumarin, quinoxaline derivatives, it is worthwhile to synthesize the compounds containing both the coumarin and quinoxaline rings in a single frame work under environmentally benign conditions. One of the most commonly used procedures for the synthesis of the quinoxaline ring that clubbed to coumarin is by the reaction of 3-(2-bromooacetyl)-2H-chromen-2-one with o-phenylenediamines. Zhou et al. reported ${ }^{23}$ the synthesis of coumarinylquinoxalines by treating 3-(2-bromoacetyl)-2H-chromen-2one with o-phenylenediamine in ethanol under microwave irradiation conditions at $100{ }^{\circ} \mathrm{C}$. Also, Kamble et al. reported ${ }^{24}$ the synthesis of coumarin and quinoxaline hybrid derivatives by the reaction of 3-(2-bromoacetyl)$2 \mathrm{H}$-chromen-2-one with o-phenylenediamine in tetrahydrofuran using pyridine as a catalyst. Thus, in the preparation of 3-(quinoxalin-2-yl)-2H-chromen-2-ones the common starting material is 3-(2-bromoacetyl)- $2 \mathrm{H}$ chromen-2-one which has to be prepared by the bromination of 3-acetyl-2H-chromen-2-one with bromine. Conventional methods of bromination of organic substrates mostly use liquid bromine as brominating reagent. However, bromine is a corrosive toxic reagent, maintenance of stoichiometry is difficult, special care is required for its storage, handling and transportation, it is very important for many organic transformations. Therefore there has been a search for benign reagents which can act as bromine alternatives. Among all the bromine alternatives that have been developed so far, a group of reagents that have become popular are the quaternary ammonium tribromides which are finding numerous applications in various bromination reactions. $^{25,26}$ Among all these, tetrabutylammonium tribromide (TBATB) has attracted the attention of researchers because of its stability, easier method of preparation and its advantages over liquid bromine such as its use at higher temperature. ${ }^{27,28}$

One-pot method of synthesis constitute one of the most effective tools in emerging organic chemistry, since they have features that contribute to an ideal synthesis such as atom economy, rapid and easy implementation, energy and time saving, eco-friendly methods with target and diversity-oriented synthesis. ${ }^{29}$ Development of new one-pot reactions towards pharmacologically active scaffolds is inevitable at the present time whereby a starting material is subjected to successive chemical operations in a single reaction vessel. So, with the above literature precedence, herein we wish to report an efficient environmentally benign one-pot method for the synthesis of 3-(quinoxalin-2-yl)-2H-chromen-2-ones using TBATB as the reagent by the direct reaction of 3-acetyl-2H-chromen-2-ones with o-phenylenediamines.

\section{Results and Discussion}

As shown in Scheme 1, reaction of commercially available salicylaldehydes with ethyl acetoacetate in ethanol containing catalytic amount of piperidine as a catalyst at room temperature (RT) for $2 \mathrm{~h}$ afforded 3-acetyl-2Hchromen-2-ones (1). Bromination of the latter with TBATB in PEG-600 at RT for $1 \frac{1}{2} \mathrm{~h}$ resulted in the formation of 3-(2-bromoacetyl)-2H-chromen-2-ones (2) (Scheme 1).

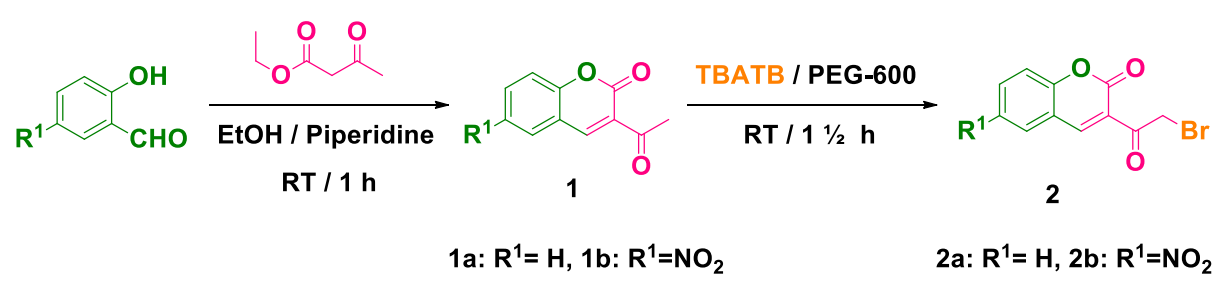

Scheme 1. Synthesis of 3-(2-bromoacetyl)-2H-chromen-2-one (2) starting from salicylaldehydes 
Reaction of 3-(2-bromoacetyl)-2H-chromen-2-one (2a, i.e., 2, $\mathrm{R}_{1}=\mathrm{H}$ ), with equimolar amount of ophenylenediamine (3a, i.e., 3, $\mathrm{R}_{2}=\mathrm{H}$ ) in PEG-600 at $100{ }^{\circ} \mathrm{C}$ for $45 \mathrm{~min}$. resulted in the formation of 3(quinoxalin-2-yl)-2H-chromen-2-one (4a, i.e., 4, $\mathrm{R}_{1}=\mathrm{R}_{2}=\mathrm{H}$ ) (Scheme 2).

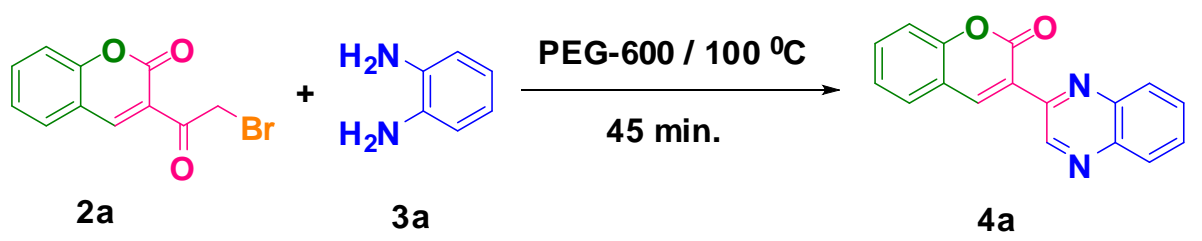

Scheme 2. Synthesis of 3-(quinoxalin-2-yl)-2H-chromen-2-one (4a) from 2a \& $3 a$.

In order to check the effect of solvent on this reaction, several solvents have been screened to get the product $\mathbf{4 a}$ in shorter time with maximum yield. When this reaction has been carried out using different solvents, resulted in the formation of product $\mathbf{4 a}$, but none of them were superior to PEG-600 (Table 1). Optimization data with several solvents has revealed that this reaction was found to complete very smoothly when PEG-600 was used as a reaction media in terms of product yield and reaction time (Table 1).

Table 1. Optimization of reaction conditions for the synthesis of $4 a$ from $2 a$ \& $3 a$

\begin{tabular}{ccccc}
\hline S. No. & Solvent & Reaction condition & Reaction Time & Yield $^{\#}(\%)$ \\
\hline 1 & PEG-600 & $100{ }^{\circ} \mathrm{C}$ & $45 \mathrm{~min}$. & 89 \\
2 & Isopropyl alcohol & $83^{\circ} \mathrm{C}$ & $2.5 \mathrm{~h}$ & 66 \\
3 & Ethylene glycol & $100^{\circ} \mathrm{C}$ & $2 \mathrm{~h}$ & 76 \\
4 & Glycerol & $100^{\circ} \mathrm{C}$ & $1.5 \mathrm{~h}$ & 79 \\
5 & Ethanol & $78{ }^{\circ} \mathrm{C}$ & $2 \mathrm{~h}$ & 74 \\
6 & Acetonitrile & $82^{\circ} \mathrm{C}$ & $2.5 \mathrm{~h}$ & 70 \\
7 & Methanol & $65^{\circ} \mathrm{C}$ & $3 \mathrm{~h}$ & 68 \\
8 & Tetrahydrofuran & $66^{\circ} \mathrm{C}$ & $2.5 \mathrm{~h}$ & 65 \\
9 & 1,4-dioxane & $101^{\circ} \mathrm{C}$ & $2 \mathrm{~h}$ & 62 \\
10 & Acetone & $56^{\circ} \mathrm{C}$ & $4.5 \mathrm{~h}$ & 58 \\
\hline
\end{tabular}

\# isolated yield

Having optimized the reaction conditions in hand, this protocol was generalized and was successfully extended to other derivatives of 3-(2-bromoacetyl)-2H-chromen-2-ones (2) and o-phenylenediamines (3) (Scheme 3). 


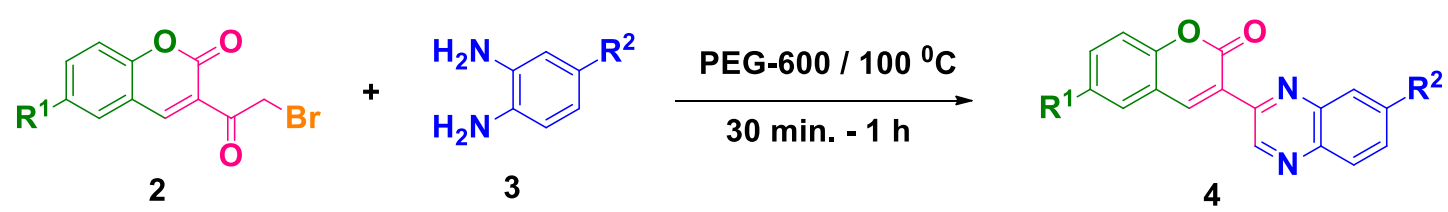

$$
\begin{array}{rr}
\text { 2a: } R^{1}=H ; & \text { 3a: } R^{2}=H ; 3 b: R^{2}=\mathrm{CH}_{3} ; \\
\text { 2b: } R^{1}=\mathrm{NO}_{2} & \text { 3c: } R^{2}=\mathrm{OH}_{3} ; 3 d: R^{2}=\mathrm{NO}_{2} ; \\
\text { 3e: } R^{2}=\mathrm{F} ; 3 f: R^{2}=\mathrm{Cl}
\end{array}
$$

4a: $R^{1}=H, R^{2}=H ; 4 b: R^{1}=H, R^{2}=C_{3}$; 4c: $R^{1}=\mathrm{H}, \mathrm{R}^{2}=\mathrm{OCH}_{3} ; 4 \mathrm{~d}: \mathrm{R}^{1}=\mathrm{H}, \mathrm{R}^{2}=\mathrm{NO}_{2}$; 4e: $R^{1}=H, R^{2}=F ; 4 f: R^{1}=H, R^{2}=C l$; 4g: $\mathbf{R}^{1}=\mathrm{NO}_{2}, \mathrm{R}^{2}=\mathrm{H} ; \mathbf{4 h}: \mathrm{R}^{1}=\mathrm{NO}_{2}, \mathrm{R}^{2}=\mathrm{CH}_{3}$; 4i: $R^{1}=\mathrm{NO}_{2}, \mathrm{R}^{2}=\mathrm{OCH}_{3} ; 4 \mathrm{j}: \mathrm{R}^{1}=\mathrm{NO}_{2}, \mathrm{R}^{2}=\mathrm{NO}_{2}$; 4k: $R^{1}=\mathrm{NO}_{2}, \mathbf{R}^{2}=\mathrm{F} ; 4 I: \mathbf{R}^{1}=\mathrm{NO}_{2}, \mathrm{R}^{2}=\mathrm{Cl}$

Scheme 3. Synthesis of 3-(quinoxalin-2-yl)-2H-chromen-2-ones (4a-I).

Encouraged with the above results, we thought of interest to prepare these compounds in a one-pot method from 3-acetyl-2H-chromen-2-ones (1). For this, in a blank experiment, we have taken equimolar amounts of 3-acetyl-2H-chromen-2-one (1a) and o-phenylenediamine (3a) and heated to $100{ }^{\circ} \mathrm{C}$ in PEG-600 to check whether any reaction taking place between $\mathbf{1 a}$ and $\mathbf{3 a}$ to form Schiff's base under our reaction conditions. We observed no product formation between these two reactants and the starting materials were recovered (Scheme 4).

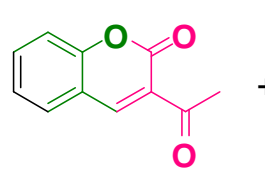

1 a

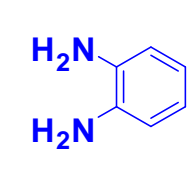

$3 a$

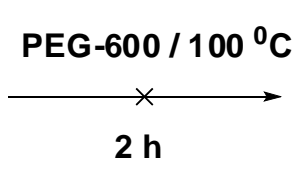

$2 \mathbf{h}$

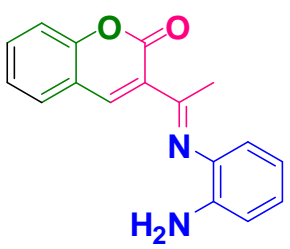

Scheme 4. Attempted reaction for the possibility of Schiff's base between 1a \& $3 a$.

With the above experiment, we understood that there is no problem of Schiff's base formation and this has been taken as an advantage, tried to prepare the target compounds in a one-pot method using TBATB as the bromine source for in-situ $\alpha$-bromination of 1 . Thus equimolar amounts of 3-acetyl-2H-chromen-2-one (1a), TBATB and o-phenylenediamine (3a) were reacted together in PEG-600 at $100{ }^{\circ} \mathrm{C}$ for $1 \mathrm{~h}$. Interestingly, this reaction was successfully completed and gave the desired product i.e., 3-(quinoxalin-2-yl)-2H-chromen-2one (4a). Thus, we have extended the scope of this one-pot protocol for various 3-acetyl-2H-chromen-2-ones (1) and o-phenylenediamines (4) to obtain the required quinoxalines (4a-I) in excellent yields. (Scheme 5). 


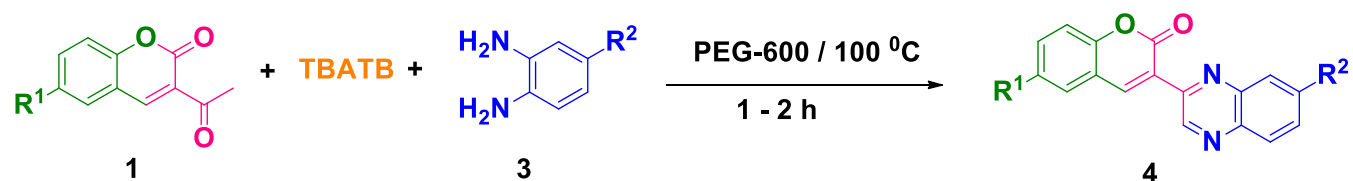

1a: $R^{1}=H$;

1b: $\mathrm{R}^{1}=\mathrm{NO}_{2}$ 3a: $\mathbf{R}^{2}=\mathrm{H}$; 3b: $\mathbf{R}^{2}=\mathrm{CH}_{3}$;

3c: $\mathrm{R}^{2}=\mathrm{OCH}_{3} ; 3 \mathrm{~d}: \mathrm{R}^{2}=\mathrm{NO}_{2}$;

3e: $\mathbf{R}^{2}=\mathrm{F} ; 3 f: \mathbf{R}^{2}=\mathrm{Cl}$ 4a: $R^{1}=H, R^{2}=H ; 4 b: R^{1}=H, R^{2}=C_{3}$;

4c: $\mathbf{R}^{1}=\mathrm{H}, \mathrm{R}^{2}=\mathrm{OCH}_{3} ; 4 \mathrm{~d}: \mathbf{R}^{1}=\mathrm{H}, \mathrm{R}^{2}=\mathrm{NO}_{2}$;

4e: $R^{1}=H, R^{2}=F ; 4 f: R^{1}=H, R^{2}=C l$;

4g: $\mathbf{R}^{1}=\mathrm{NO}_{2}, \mathbf{R}^{2}=\mathrm{H} ; \mathbf{4 h}: \mathbf{R}^{1}=\mathrm{NO}_{2}, \mathbf{R}^{2}=\mathrm{CH}_{3}$;

4i: $\mathbf{R}^{1}=\mathrm{NO}_{2}, \mathbf{R}^{2}=\mathrm{OCH}_{3} ; 4 \mathrm{j}: \mathbf{R}^{1}=\mathrm{NO}_{2}, \mathbf{R}^{2}=\mathrm{NO}_{2}$;

4k: $\mathbf{R}^{1}=\mathrm{NO}_{2}, \mathbf{R}^{2}=\mathrm{F} ; 4 \mathrm{I}: \mathbf{R}^{1}=\mathrm{NO}_{2}, \mathbf{R}^{2}=\mathrm{Cl}$

Scheme 5. One-pot synthesis of 3-(quinoxalin-2-yl)-2H-chromen-2-ones (4a-I) from 1.

The mechanism for this one-pot reaction was studied and here TBATB can be considered as a general brominating agent where it reacts with 3-acetyl-2H-chromen-2-one (1) in PEG-600 to give the corresponding 3-(2-bromoacetyl)-2H-chromen-2-one (2), $\mathrm{HBr}$ and tetrabutylammonium bromide (TBAB). 2 thus, formed in this way can be readily reacted in situ with o-phenylenediamines (4) to give the corresponding quinoxalines 4. The beauty of this reaction is that TBATB during its reaction generates TBAB, which will be in the reaction mass, and will then act as a Phase Transfer Catalyst (PTC) and enhance the progress of the condensation reaction (alkylation of $\mathbf{3}$ by bromoacetyl group) between $\mathbf{2} \& \mathbf{3}$ in-situ (Scheme 6). In detail, $\alpha$-bromoacetyl group of $\mathbf{2}$ initially undergo nucleophilic substitution reaction with one of the amine from o-phenylenediamine (3) to form a condensed product " $A$ ". Another amine from this condensed compound " $A$ " will undergo internal nucleophilic addition reaction with carbonyl carbon to form a cyclized compound "B" which will undergo dehydration to form " $\mathbf{C}$ ". The latter being the dihydroderivative, quite unstable, undergoes dehydrogenation (oxidation) under heating conditions to yield the thermally stable, aromatized product quinoxaline 4.

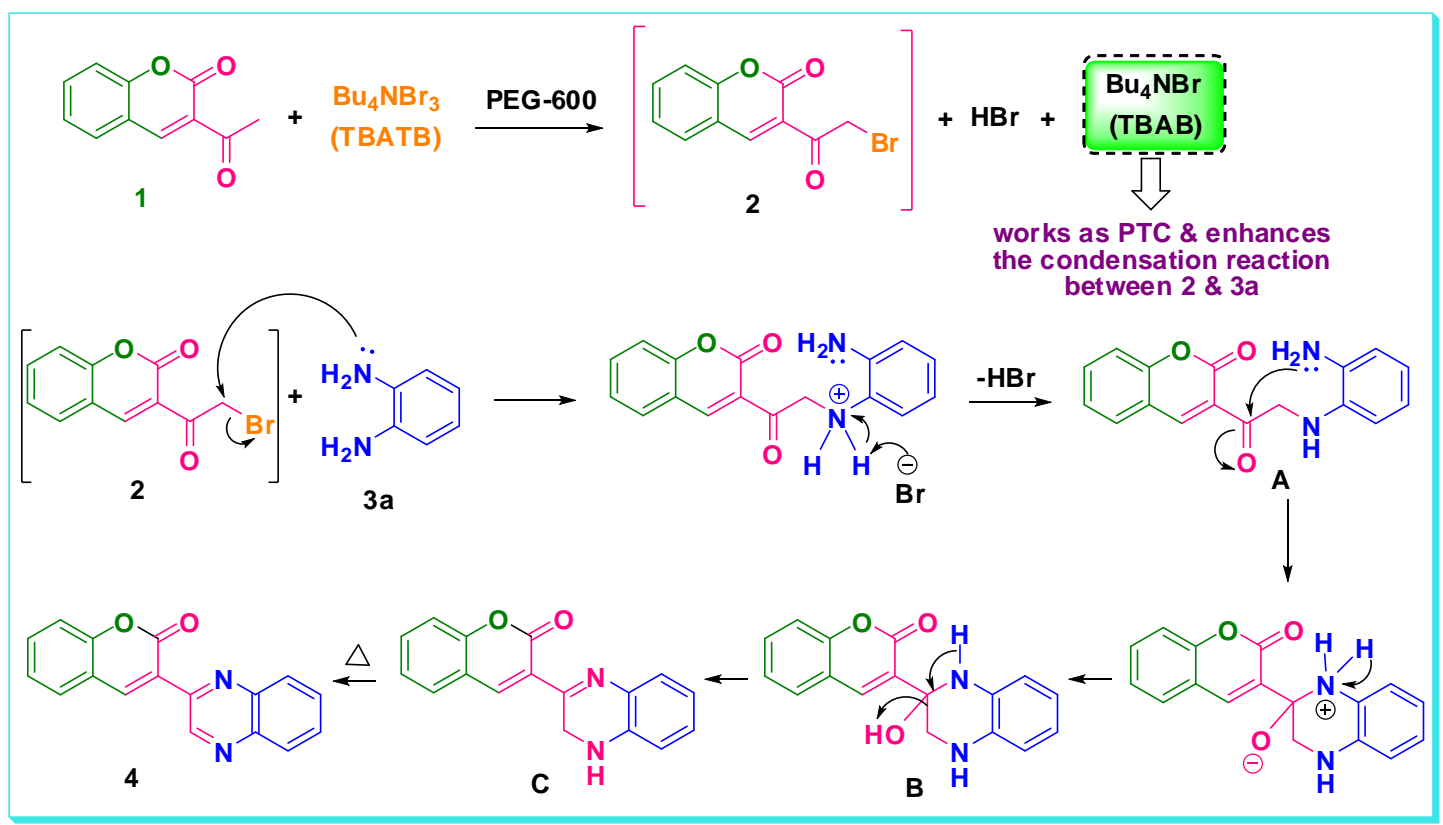

Scheme 6. Plausible mechanism for the formation of 3-(quinoxalin-2-yl)-2H-chromen-2-one (4). 
The overall yield from the stepwise synthesis for the formation of $\mathbf{4}$ has been calculated (Table 2) and compared with the yield of $\mathbf{4}$ obtained from the one-pot synthesis (Figure 3). From this comparison, it can be concluded that one-pot synthesis is the most convenient and efficient method for the preparation of these quinoxalines.

Table 2. Comparison of yields of 4 obtained in step-wise \& One-pot method

\begin{tabular}{|c|c|c|c|c|}
\hline \multirow[t]{2}{*}{ S. No. } & \multicolumn{3}{|c|}{ Step-Wise method } & \multirow{2}{*}{$\begin{array}{l}\text { Yield of } 4 \text { obtained } \\
\text { in One-pot method }\end{array}$} \\
\hline & $\begin{array}{c}\text { Yield of } \mathbf{2} \\
\text { from } 1 \\
\end{array}$ & $\begin{array}{c}\text { Yield of } 4 \\
\text { from } 2 \text { \& } 3\end{array}$ & $\begin{array}{c}\text { Overall } \\
\text { yield of } 4\end{array}$ & \\
\hline 1 & 2a: 93 & 4a: 88 & 4a: 82 & 4a: 90 \\
\hline 2 & 2a: 93 & 4b: 76 & 4b: 70 & 4b: 77 \\
\hline 3 & 2a: 93 & 4c: 73 & 4c: 67 & 4c: 76 \\
\hline 4 & 2a: 93 & 4d: 84 & 4d: 78 & 4d: 87 \\
\hline 5 & 2a: 93 & 4e: 77 & 4e: 72 & 4e: 84 \\
\hline 6 & 2a: 93 & 4f: 81 & 4f: 75 & 4f: 83 \\
\hline 7 & 2b: 89 & 4g: 78 & 4g: 69 & 4g: 78 \\
\hline 8 & 2b: 89 & 4h: 75 & 4h: 67 & 4h: 75 \\
\hline 9 & 2b: 89 & 4i: 73 & 4i: 65 & 4i: 77 \\
\hline 10 & 2b: 89 & 4j: 82 & 4j: 73 & 4j: 89 \\
\hline 11 & 2b: 89 & 4k: 80 & 4k: 71 & 4k: 82 \\
\hline 12 & 2b: 89 & 4I: 79 & 41: 70 & 4I: 85 \\
\hline
\end{tabular}

\section{comparision table between step- wise and one-pot method}

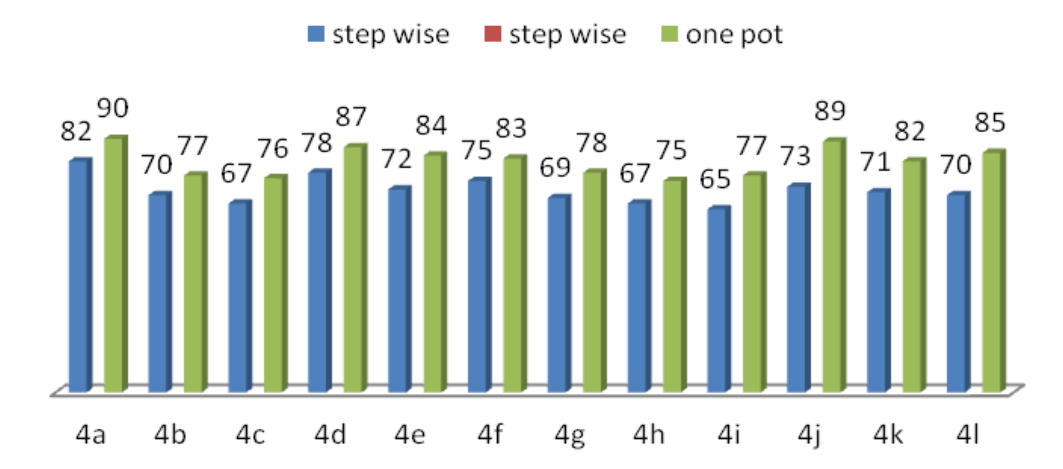

Figure 3. Yield comparison of step-wise as well as one-pot method for the synthesis of 4.

\section{Synthesis of TBATB}

A mixture of TBAB $(38.80 \mathrm{~g}, 120 \mathrm{mmol})$, sodium bromate $(6.00 \mathrm{~g}, 40 \mathrm{mmol})$ and water $(300 \mathrm{~mL})$ was stirred at room temperature for $10 \mathrm{~min}$. To this solution was added $48 \% \mathrm{Aq} . \mathrm{HBr}(28 \mathrm{~mL})$ drop wise under stirring and continued for another $30 \mathrm{~min}$ at room temperature. An orange colored solid precipitated out, which was filtered, washed with water $(2 \times 120 \mathrm{~mL})$ and air-dried at room temperature.

Yield: $55.36 \mathrm{~g}(96 \%) . \mathrm{mp} 74-76^{\circ} \mathrm{C}$. 


\section{Characterization of TBATB}

Formation of the reagent TBATB was compared with the available literature data, however, further characterization is always an added advantage. In view of this, we have characterized TBATB with powder XRD, SEM-EDX, DSC and TG/DTA analysis.

\section{SEM-EDX analysis of TBATB}

The surface morphology of TBATB was studied by recording its SEM micrograph. These SEM images (Figure 4) showed proper alignment and an even distribution which was recorded at different magnifications. Further, the elemental composition of the material has been came to know with the help of EDX analysis (Figure 5). For this reagent, EDX analysis showed the presence of $\mathrm{C}, \mathrm{N}$ and $\mathrm{Br}$ elements.
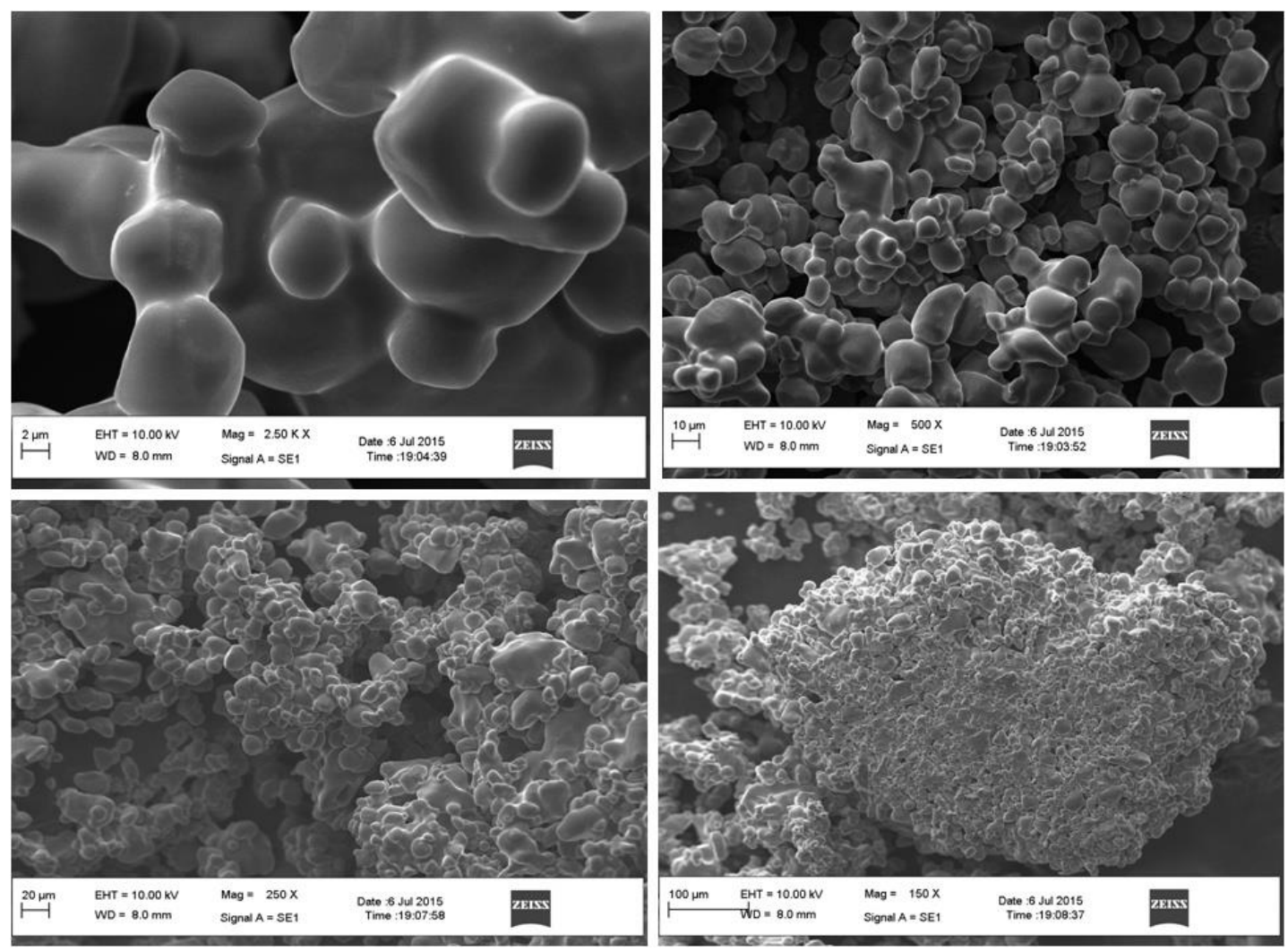

Figure 4. SEM image of TBATB at different magnifications.

\begin{tabular}{l|ll}
\hline Element & Weight $\%$ & Atomic\% \\
C K & 46.50 & 76.58 \\
N K & 7.23 & 10.21 \\
Br L & 46.26 & 13.21 \\
Totals & 100.00 & \\
\hline
\end{tabular}

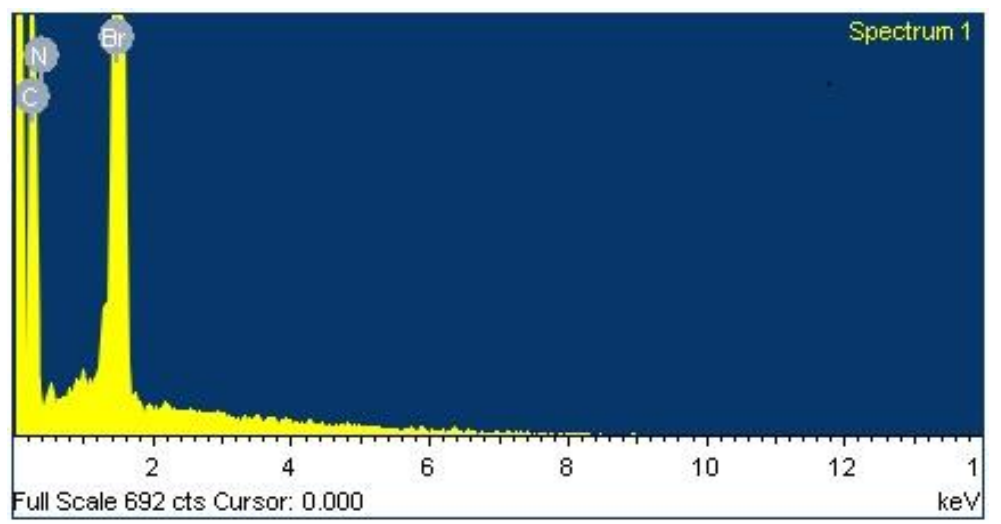

Figure 5. EDX analysis of TBATB. 


\section{Powder X-ray diffraction (XRD) analysis of TBATB}

The nature of the prepared TBATB was identified by recording its powder XRD. X-ray patterns of TBATB was recorded at 2 theta $=10-80^{\circ}$ range (Figure 6). A broad peak centered at 2 theta angle showed the strong crystalline peaks in the range of $10-60^{\circ}$ confirmed the TBATB reagent as crystalline in nature.

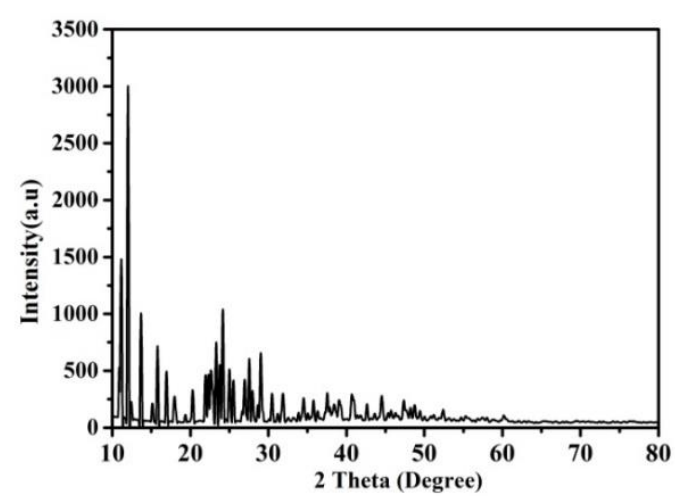

Figure 6. Powder X-ray diffraction analysis of TBATB.

\section{TG/DTA analysis of TBATB}

Further the scope and the stability of the reagent at higher temperatures were studied by TG-DTA analysis. DSC measures amount of energy released or absorbed by the sample when it is cooled or heated, providing quantitative and qualitative data on endothermic (heat absorption) and exothermic (heat evolution) processes and the main advantage of DSC is to measure melting temperature. The melting endotherm for TBATB after heating is shown an enthalpy of $278.6 \mathrm{~J} / \mathrm{g}$ (Figure 7).

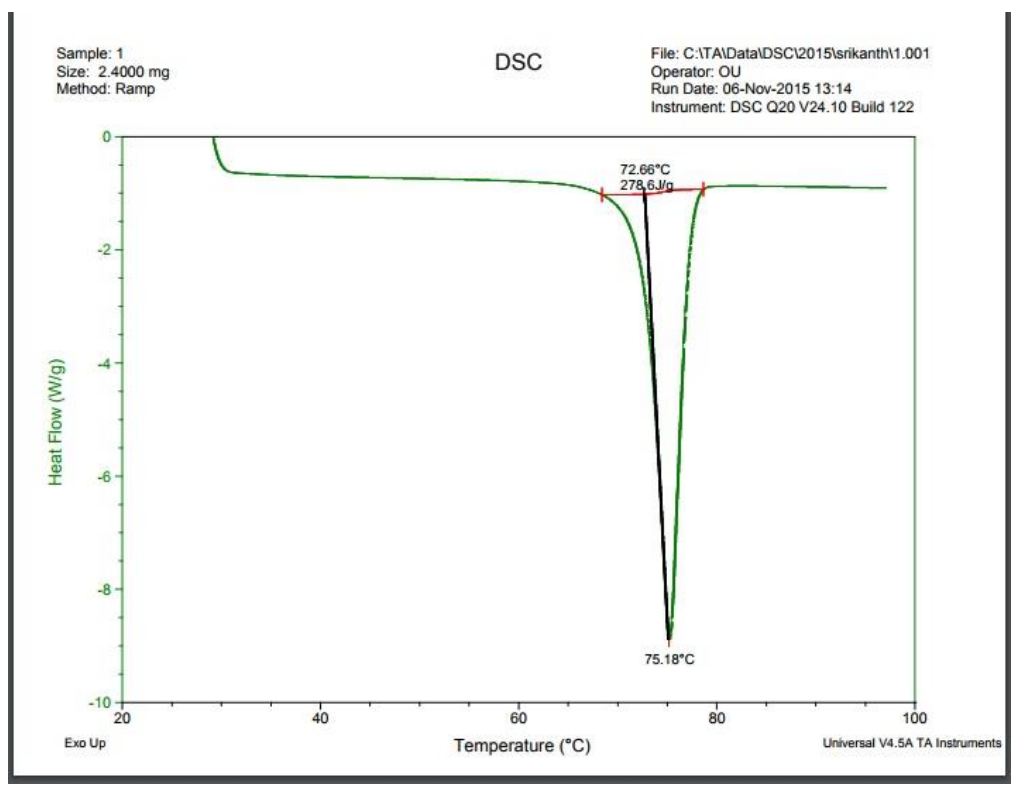

Figure 7. DSC curve of TBATB.

Differential thermal analysis (DTA) and thermo gravimetric analysis (TGA) of the prepared reagent, i.e., TBATB has also been carried out simultaneously. Thermal stability of the reagent was tested by heating the 
reagent at a rate of $5^{\circ} \mathrm{C} / \mathrm{min}$ under inert nitrogen atmosphere. In DTA curve, the first endothermic peak at 75 ${ }^{\circ} \mathrm{C}$ is due to its meting point, which is also evident from the DSC curve. Another important observation in TGA is there was no phase transition observed till the material melts which showed that this reagent can withstand higher temperatures (Figure 8).

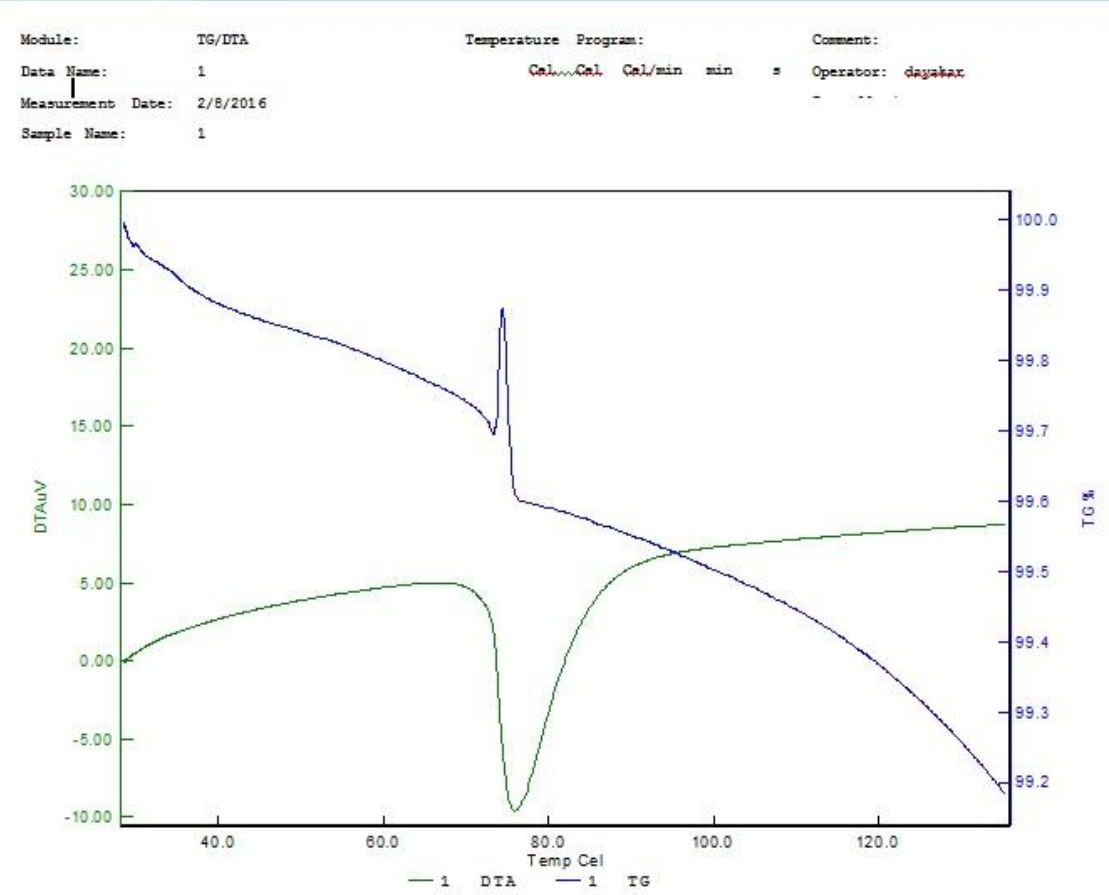

Figure 8. TG-DTA curves of TBATB.

\section{Conclusions}

In conclusion, we have established an efficient one-pot three component method for the synthesis of 3(quinoxalin-2-yl)-2H-chromen-2-ones in PEG-600 as the green reaction media. This one-pot method worked very efficiently and effectively for the synthesis of 3-(quinoxalin-2-yl)-2H-chromen-2-ones by cutting down the number of steps, lowering the reaction time and relieving from the difficulty of isolating the compounds in every step and their purifications. The method applied for this synthesis is regarded as environmentally harmless by avoiding the harmful toxic chemical, i.e., liquid bromine, and the harmful carcinogenic solvents. Synthesis carried in stepwise process also and compared the yield of the products among the two methods and the one-pot method found to be superior among the two. The exploration of bromine alternative lead us to a safe, easily handlable reagent i.e., TBATB, which is paved a way for the emerging researchers in the particular field of interest.

\section{Experimental Section}

General. Melting points are uncorrected and were determined in open capillary tubes using sulphuric acid bath. TLC analyses were done on silica gel-G coated sheets supplied by Merck Company and visualization was 
done using UV lamp and iodine. ${ }^{1} \mathrm{H}$ NMR spectra were recorded in DMSO- $d_{6}$ using TMS as an internal standard using $400 \mathrm{MHz}$ spectrometer. Mass spectra were recorded on Agilent-LCMS instrument. Starting materials like salicylaldehyde, ethyl acetoacetate, o-phenylenediamines were purchased from commercial suppliers and used as such.

General procedure for the preparation of 2 from 1. A mixture of 1 (20 mmol), TBATB (20 mmol), PEG-600 (30 $\mathrm{mL}$ ) was stirred at RT for $1-1 \frac{1}{2} \mathrm{~h}$. After completion of the reaction, the mixture was poured into ice-cold water $(60 \mathrm{~mL})$. The separated solid was filtered, washed with water $(2 \times 30 \mathrm{~mL})$ and air-dried at RT. The crude product was recrystallized from suitable solvent to obtain pure 2.

3-(2-Bromoacetyl)-2H-chromen-2-one (2a): White color solid. Yield: $4.96 \mathrm{~g}$ (93 \%). mp: 165-167 ${ }^{\circ} \mathrm{C}$ [23]; IR $(\mathrm{KBr}) \mathrm{vmax} / \mathrm{cm}^{-1}: 1717 \mathrm{~cm}^{-1}$ (strong, sharp, -CO of coumarin ring), 1683 (CO of $-\mathrm{COCH}_{3}$ ); ${ }^{1} \mathrm{H}-\mathrm{NMR}(400 \mathrm{MHz}$, DMSO- $d_{6} / \mathrm{TMS}$ ): $\delta 4.68$ (s, 2H, $-\mathrm{CH}_{2}$ ), 7.35-8.00 (complex, multiplet, 4H, Ar-H), 8.68 (s, $1 \mathrm{H}, \mathrm{Ar}-\mathrm{H}$ ); ${ }^{13} \mathrm{C}-\mathrm{NMR}(100$ $\mathrm{MHz}$, DMSO- $\left.d_{6}\right)$ : 36.3, 116.2, 118.2, 122.8, 125.1, 131.0, 135.0, 148.5, 152.3, 163.6, 190.3; HRMS calculated for $\mathrm{C}_{11} \mathrm{H}_{7} \mathrm{BrO}_{3}[\mathrm{M}+\mathrm{H}]^{+}:$:266.9656, found: 266.9697.

3-(2-Bromoacetyl)-6-nitro-2H-chromen-2-one (2b). White color solid. Yield: $5.55 \mathrm{~g}$ (89 \%). $\mathrm{mp}: 145-147{ }^{\circ} \mathrm{C}$ [23]; IR ( $\mathrm{KBr}$ ) vmax/cm ${ }^{-1}: 1726 \mathrm{~cm}^{-1}$ (strong, sharp, -CO of coumarin ring), 1685 (CO of - $\left.\mathrm{COCH}_{3}\right) ;{ }^{1} \mathrm{H}-\mathrm{NMR}(400$ $\mathrm{MHz}, \mathrm{DMSO}-d_{6} / \mathrm{TMS}$ ): $\delta 4.80$ (s, 2H, $-\mathrm{CH}_{2}$ ), 7.35-7.54 (complex, multiplet, 2H, Ar-H), 7.98 (s, $\left.1 \mathrm{H}, \mathrm{Ar}-\mathrm{H}\right), 8.68$ (s, $1 \mathrm{H}, \mathrm{Ar}-\mathrm{H}) ;{ }^{13} \mathrm{C}-\mathrm{NMR}(100 \mathrm{MHz}$, DMSO-d $)$ : 36.5, 116.5, 118.8, 122.8, 125.6, 132.0, 140.8, 148.8, 153.2, 164.2, 190.9; $\mathrm{HRMS}$ calculated for $\mathrm{C}_{11} \mathrm{H}_{6} \mathrm{BrNO}_{5}[\mathrm{M}+\mathrm{H}]^{+}: 311.9507$, found: 311.9576 .

General procedure for the synthesis of 4 from 2 \& 3. A mixture of 2 (10 mmol), 3 (10 mmol) in PEG-600 $(20 \mathrm{~mL})$ was heated to $100{ }^{\circ} \mathrm{C}$ and maintained for a period of $30 \mathrm{~min}$. to $1 \mathrm{~h}$. After completion of the reaction, the mixture was poured into ice-cold water $(60 \mathrm{~mL})$. The separated solid was filtered, washed with water $(2 \times 30 \mathrm{~mL})$ and air-dried at RT. The crude product was recrystallized from suitable solvent to obtain pure 4 .

3-(Quinoxalin-2-yl)-2H-chromen-2-one (4a). Brown color solid. Yield: $2.41 \mathrm{~g}$ (88\%); $\mathrm{mp}: 198-200{ }^{\circ} \mathrm{C}$ (Methanol); IR (KBr) vmax/cm ${ }^{-1}: 1715 \mathrm{~cm}^{-1}$ (strong, sharp, -CO of coumarin ring); ${ }^{1} \mathrm{H}-\mathrm{NMR}\left(400 \mathrm{MHz}, \mathrm{DMSO}-d_{6} /\right.$ TMS): $\delta$ 7.34-8.36 (complex, multiplet, 8H, Ar- H), 8.87 (s, 1H, Ar-H), 9.55 (s, 1H, Ar-H ); ${ }^{13} \mathrm{C}-\mathrm{NMR}(100 \mathrm{MHz}$, DMSO-d $)_{6}$ : 116.1, 119.0, 123.5, 124.9, 128.8, 129.0, 129.7, 130.5, 130.7, 133.2, 141.2, 144.5, 145.3, 147.7, 153.8, 159.5; HRMS calculated for $\mathrm{C}_{17} \mathrm{H}_{10} \mathrm{~N}_{2} \mathrm{O}_{2}[\mathrm{M}+\mathrm{H}]^{+}:$: 275.08205, found: 275.0821.

3-(7-Methylquinoxalin-2-yl)-2H-chromen-2-one (4b). Brown color solid. Yield: $2.18 \mathrm{~g}$ (76\%); $\mathrm{mp:} 190-192{ }^{\circ} \mathrm{C}$ (Ethanol); IR(KBr) vmax/ cm-1: $1715 \mathrm{~cm}^{-1}$ (strong, sharp, -CO of coumarin ring); ${ }^{1} \mathrm{H} \mathrm{NMR}\left(400 \mathrm{MHz}, \mathrm{DMSO}-d_{6} /\right.$ TMS): $\delta 2.43$ (s, 3H, CH CH, $7.38-8.12$ (complex, m, 7H, Ar-H), $8.83(\mathrm{~s}, 1 \mathrm{H}, \mathrm{Ar}-\mathrm{H}), 9.54(\mathrm{~s}, 1 \mathrm{H}, \mathrm{Ar}-\mathrm{H}) ;{ }^{13} \mathrm{C} \mathrm{NMR}(100$ $\left.\mathrm{MHz}, \mathrm{DMSO}-d_{6}\right): 21.3,116.0,119.0,124.9,127.6,128.3,128.5,129.6,133.1,139.7,140.9,141.4,144.1,144.3$, 145.1, 147.4, 153.7, 159.5; HRMS calculated for $\mathrm{C}_{18} \mathrm{H}_{12} \mathrm{~N}_{2} \mathrm{O}_{2}[\mathrm{M}+\mathrm{H}]^{+}:$: 289.09710, Found: 289.09662.

3-(7-Methoxyquinoxalin-2-yl)-2H-chromen-2-one (4c). Brown color solid. Yield: $2.21 \mathrm{~g}(73 \%)$; mp: 156-158 ${ }^{\circ} \mathrm{C}$ (Ethanol); IR(KBr) vmax/ cm ${ }^{-1}: 1720 \mathrm{~cm}^{-1}$ (strong, sharp, -CO of coumarin ring); ${ }^{1} \mathrm{H} \mathrm{NMR}\left(400 \mathrm{MHz}, \mathrm{DMSO}-d_{6} /\right.$ $\mathrm{TMS}): \delta 3.96\left(\mathrm{~s}, 3 \mathrm{H}, \mathrm{OCH}_{3}\right), 7.43-8.06$ (complex, m, 7H, Ar-H), 8.90 (s, 1H, Ar-H), 9.52 (s, 1H, Ar-H); ${ }^{13} \mathrm{C} \mathrm{NMR}$ (100 MHz, DMSO-d $\left.d_{6}\right): 51.3,117.5,117.6,128.3,128.5,129.6,130.7,132.7,132.8,133.1,134.4,139.7,140.8$, 141.4, 144.0, 144.3, 155.1, 167.0; HRMS calculated for $\mathrm{C}_{18} \mathrm{H}_{12} \mathrm{~N}_{2} \mathrm{O}_{3}[\mathrm{M}+\mathrm{H}]^{+}: 305.09261$, Found: 305.09245.

3-(7-Nitroquinoxalin-2-yl)-2H-chromen-2-one (4d). Brown color solid. Yield: $2.67 \mathrm{~g}$ (84\%); $\mathrm{mp}: 240-242{ }^{\circ} \mathrm{C}$ (Methanol); IR(KBr) vmax/ cm-1 $1723 \mathrm{~cm}^{-1}$ (strong, sharp, -CO of coumarin ring); ${ }^{1} \mathrm{H} \mathrm{NMR}\left(400 \mathrm{MHz}, \mathrm{DMSO}-d_{6} /\right.$ TMS): $\delta$ 7.44-8.06 (complex, m, 7H, Ar-H), 8.91 (s, 1H, Ar-H), 9.55 (s, 1H, Ar-H); ${ }^{13} \mathrm{C} \mathrm{NMR} \mathrm{(100} \mathrm{MHz,} \mathrm{DMSO-d} 6$ ): 127.6, 128.3, 128.5, 129.6, 130.7, 132.7, 132.8, 133.1, 134.4, 139.7, 141.4, 144.3, 145.1, 147.0, 147.4, 153.7, 159.5; HRMS calculated for $\mathrm{C}_{17} \mathrm{H}_{9} \mathrm{~N}_{3} \mathrm{O}_{4}[\mathrm{M}+\mathrm{H}]+$ : 320.06713 , Found: 320.06728. 
3-(7-Fluoroquinoxalin-2-yl)-2H-chromen-2-one (4e). Brown color solid. Yield: $2.25 \mathrm{~g}$ (77\%); mp: $167-169{ }^{\circ} \mathrm{C}$ (Methanol); IR( $\mathrm{KBr}$ ) vmax/ cm ${ }^{-1}: 1725 \mathrm{~cm}^{-1}$ (strong, sharp, -CO of coumarin ring), ${ }^{1} \mathrm{H} \mathrm{NMR}\left(400 \mathrm{MHz}, \mathrm{DMSO}-d_{6} /\right.$ TMS): $\delta$ 7.44-8.06 (complex, m, 7H, Ar-H), 8.90 (s, 1H, Ar-H), 9.55 (s, $1 \mathrm{H}, \mathrm{Ar}-\mathrm{H}$ ); ${ }^{13} \mathrm{C}$ NMR (100 MHz, DMSO- $\left.d_{6}\right)$ : 127.7, 128.3, 128.5, 129.6, 132.7, 132.8, 133.1, 139.7, 140.9, 141.2, 141.4, 144.1, 144.3, 145.1, 147.5, 153.7, 159.5; HRMS calculated for $\mathrm{C}_{17} \mathrm{H}_{9} \mathrm{FN}_{2} \mathrm{O}_{2}[\mathrm{M}+\mathrm{H}]+:$ 293.07263, Found: 293.07219.

3-(7-Chloroquinoxalin-2-yl)-2H-chromen-2-one (4f). Brown color solid. Yield: $2.50 \mathrm{~g}(81 \%) ; \mathrm{mp}: 185-187{ }^{\circ} \mathrm{C}$ (Acetone); IR( $\mathrm{KBr}$ ) vmax/ cm-1: $1718 \mathrm{~cm}^{-1}$ (strong, sharp, -CO of coumarin ring); ${ }^{1} \mathrm{H} \mathrm{NMR}\left(400 \mathrm{MHz}, \mathrm{DMSO}-d_{6} /\right.$ TMS): $\delta$ 7.43-8.07 (complex, m, 7H, Ar-H), 8.89 (s, 1H, Ar-H), 9.56 (s, 1H, Ar-H); ${ }^{13} \mathrm{C}$ NMR (100 MHz, DMSO- $\left.d_{6}\right)$ : $126.9,127.7,128.2,128.9,131.9,132.2,132.9,138.2,140.5,141.2,141.8,143.9,144.1,144.9,146.9,152.6$, 158.8; $\mathrm{HRMS}$ calculated for $\mathrm{C}_{17} \mathrm{H}_{9} \mathrm{ClN}_{2} \mathrm{O}_{2}[\mathrm{M}+\mathrm{H}]+$ : 309.04308, Found: 309.04299.

6-Nitro-3-(quinoxalin-2-yl)-2H-chromen-2-one (4g). Yellow color solid. Yield: $2.48 \mathrm{~g}$ (78\%); mp: $247-249{ }^{\circ} \mathrm{C}$ (Ethanol); IR (KBr) vmax $/ \mathrm{cm}^{-1}: 1712 \mathrm{~cm}^{-1}$ (strong, sharp, -CO of coumarin ring); ${ }^{1} \mathrm{H}-\mathrm{NMR}$ (400 MHz, DMSO- $d_{6} /$ TMS): $\delta$ 7.67-8.39 (complex, multiplet, 7H, Ar- H), 8.88 (s, 1H, Ar-H), $9.60\left(\mathrm{~s}, 1 \mathrm{H}, \mathrm{Ar}-\mathrm{H}\right.$ ); ${ }^{13} \mathrm{C}-\mathrm{NMR}(100 \mathrm{MHz}$, DMSO- $\left.d_{6}\right): 118.4,123.4,124.5,124.5,128.8,129.0,129.5,129.7,129.7,142.2,143.2,144.3,144.4,146.7$, 153.8, 159.5, 161.7; HRMS calculated for $\mathrm{C}_{17} \mathrm{H}_{9} \mathrm{~N}_{3} \mathrm{O}_{4}[\mathrm{M}+\mathrm{H}]^{+}: 320.06713$, Found: 320.06245 .

3-(7-Methylquinoxalin-2-yl)-6-nitro-2H-chromen-2-one (4h): Yellow color solid. Yield: $2.66 \mathrm{~g}$ (80\%); mp: 202$204{ }^{\circ} \mathrm{C}$ (Methanol); IR(KBr) vmax/ cm ${ }^{-1}: 1734 \mathrm{~cm}^{-1}$ (strong, sharp, -CO of coumarin ring); ${ }^{1} \mathrm{H} \mathrm{NMR}(400 \mathrm{MHz}$, DMSO-d 6 / TMS): $\delta 2.43$ (s, 3H, $\mathrm{CH}_{3}$ ), 7.58-8.52 (complex, m, 6H, Ar-H), 8.83 (s, 1H, Ar-H), $9.54\left(\mathrm{~s}, 1 \mathrm{H}, \mathrm{Ar}-\mathrm{H}\right.$ ); ${ }^{13} \mathrm{C}$ NMR $\left(100 \mathrm{MHz}\right.$, DMSO- $\left.d_{6}\right): 21.3,118.0,123.0,124.6,124.9,127.3,128.5,129.6,134.1,138.7,139.9,141.4$, 142.1, 144.3, 146.1, 153.4, 159.7, 161.5; HRMS calculated for $\mathrm{C}_{18} \mathrm{H}_{11} \mathrm{~N}_{3} \mathrm{O}_{4}[\mathrm{M}+\mathrm{H}]^{+}:$: 334.08278, Found: 334.08098.

3-(7-Methoxyquinoxalin-2-yl)-6-nitro-2H-chromen-2-one (4i). Yellow color solid. Yield: 2.75 g (79\%); mp: 192$194{ }^{\circ} \mathrm{C}$ (Methanol); IR(KBr) vmax/ cm-1: $1724 \mathrm{~cm}^{-1}$ (strong, sharp, -CO of coumarin ring); ${ }^{1} \mathrm{H} \mathrm{NMR} \mathrm{(400} \mathrm{MHz,}$ DMSO-d $/$ TMS): $\delta 3.86$ (s, 3H, OCH $)_{3}$, 7.53-8.56 (complex, m, 6H, Ar-H), $8.87(\mathrm{~s}, 1 \mathrm{H}, \mathrm{Ar}-\mathrm{H}), 9.52(\mathrm{~s}, 1 \mathrm{H}, \mathrm{Ar}-\mathrm{H}$ ); ${ }^{13} \mathrm{C}$ NMR $\left(100 \mathrm{MHz}\right.$, DMSO-d $\left.d_{6}\right)$ :55.3, 103.5, 118.6, 123.3, 124.5, 124.6, 127.7, 129.8, 130.7, 137.8, 140.1, 144.4, 144.7, 146.8, 154.6, 158.4, 159.0, 161.3; HRMS calculated for $\mathrm{C}_{18} \mathrm{H}_{11} \mathrm{~N}_{3} \mathrm{O}_{5}[\mathrm{M}+\mathrm{H}]^{+}$: 350.07769, Found: 350.07812.

6-Nitro-3-(7-nitroquinoxalin-2-yl)-2H-chromen-2-one (4j). Yellow color solid. Yield: $2.98 \mathrm{~g}$ (82\%); mp: 258-260 ${ }^{\circ} \mathrm{C}$ (Acetone); IR(KBr) vmax/ cm ${ }^{-1}: 1712 \mathrm{~cm}^{-1}$ (strong, sharp, -CO of coumarin ring); ${ }^{1} \mathrm{H} \mathrm{NMR}(400 \mathrm{MHz}, \mathrm{DMSO}-$ $d_{6} / \mathrm{TMS}$ ): $\delta$ 7.64-8.56 (complex, m, 6H, Ar-H), 8.91 (s, 1H, Ar-H), 9.55 (s, 1H, Ar-H); ${ }^{13} \mathrm{C} \mathrm{NMR} \mathrm{(100} \mathrm{MHz,} \mathrm{DMSO-}$ $\left.d_{6}\right): 127.6,128.3,128.5,129.6,130.7,132.7,132.8,133.1,134.4,139.7,141.4,144.3,145.1,147.0,147.4$, 153.7, 159.5; HRMS calculated for $\mathrm{C}_{17} \mathrm{H}_{8} \mathrm{~N}_{4} \mathrm{O}_{6}[\mathrm{M}+\mathrm{H}]+$ : 365.05221 , Found: 365.05011.

3-(7-Fluoroquinoxalin-2-yl)-6-nitro-2H-chromen-2-one (4k). Yellow color solid. Yield: $2.59 \mathrm{~g}$ (77\%); mp: 231$233{ }^{\circ} \mathrm{C}$ (Methanol); IR(KBr) vmax/ cm ${ }^{-1}: 1708 \mathrm{~cm}^{-1}$ (strong, sharp, -CO of coumarin ring), ${ }^{1} \mathrm{H} \mathrm{NMR}(400 \mathrm{MHz}$, DMSO-d $d_{6}$ TMS): $\delta$ 7.44-8.56 (complex, m, 6H, Ar-H), 8.90 (s, $\left.1 \mathrm{H}, \mathrm{Ar}-\mathrm{H}\right), 9.55$ (s, $\left.1 \mathrm{H}, \mathrm{Ar}-\mathrm{H}\right) ;{ }^{13} \mathrm{C} \mathrm{NMR}(100 \mathrm{MHz}$, DMSO-d $)_{6}$ : $127.7,128.3,128.5,129.6,132.7,132.8,133.1,139.7,140.9,141.2,141.4,144.1,144.3,145.1$, 147.5, 153.7, 159.5; HRMS calculated for $\mathrm{C}_{17} \mathrm{H}_{8} \mathrm{FN}_{3} \mathrm{O}_{4}[\mathrm{M}+\mathrm{H}]+:$ : 338.05771, Found: 338.05842 .

3-(7-Chloroquinoxalin-2-yl)-6-nitro-2H-chromen-2-one (4I). Yellow color solid. Yield: $2.78 \mathrm{~g}$ (79\%); mp: 215$217{ }^{\circ} \mathrm{C}$ (Ethanol); IR(KBr) vmax/ cm${ }^{-1}: 1714 \mathrm{~cm}^{-1}$ (strong, sharp, -CO of coumarin ring); ${ }^{1} \mathrm{H} \mathrm{NMR}(400 \mathrm{MHz}$, DMSO- $d_{6} / \mathrm{TMS}$ ): $\delta$ 7.41-8.56 (complex, $\left.\mathrm{m}, 6 \mathrm{H}, \mathrm{Ar}-\mathrm{H}\right), 8.85$ (s, $\left.1 \mathrm{H}, \mathrm{Ar}-\mathrm{H}\right), 9.56$ (s, $\left.1 \mathrm{H}, \mathrm{Ar}-\mathrm{H}\right) ;{ }^{13} \mathrm{C} \mathrm{NMR}(100 \mathrm{MHz}$, DMSO-d $)_{6}$ : $68.3,111.4,115.8,120.0,125.9,127.7,129.2,130.9,131.9,139.2,139.9,140.2,142.5,143.2$, 143.8, 154.9, 163.7; HRMS calculated for $\mathrm{C}_{17} \mathrm{H}_{8} \mathrm{ClN}_{3} \mathrm{O}_{4}[\mathrm{M}+\mathrm{H}]+:$ 354.02816, Found: 354.02924 .

General procedure for the one-pot three component synthesis of 4 from 1 \& 3. A mixture of 1 (10 mmol), TBATB $(10 \mathrm{mmol}), 3(10 \mathrm{mmol})$ and PEG-600 $(20 \mathrm{~mL})$ was heated to $100{ }^{\circ} \mathrm{C}$ and maintained at the same 
temperature for a period of 1-2 $\mathrm{h}$. Progress of the reaction was monitored on TLC. After completion of reaction, the mixture was poured into ice-cold water $(60 \mathrm{~mL})$. The separated solid was filtered, washed with water $(2 \times 30 \mathrm{~mL})$ and dried. The crude product was recrystallized from a suitable solvent to obtain pure 4 .

\section{Acknowledgements}

Authors are sincerely thankful to the authorities of Jawaharlal Nehru Technological University Hyderabad, for providing laboratory facilities to carry out the research work. One of the author (KK) is grateful for the financial support in the form of Lectureship.

\section{Supplementary Material}

Characterization data (for all new products), copies of ${ }^{1} \mathrm{H}$ and ${ }^{13} \mathrm{C}$ NMR, HRMS and IR spectra are reported in the Supplementary Material associated with this paper.

\section{References}

1. Venugopala, K. N.; Rashmi, V.; Odhav, B. Biomed Res. Int. 2013, 43, 1-14. http://dx.doi.org/10.1155/2013/963248

2. Atul, M.; Alpeshkumar, M.; Jitender, V.; Vijay, V.; Arun, M.; Kuldip, U. Eur. J. Med. Chem. 2008, 43, 23952403.

https://doi.org/10.1016/j.ejmech.2008.01.016

3. Manolov, I.; Danchev, N.D. Eur. J. Med. Chem. 1995, 30, 531-535. https://doi.org/10.1016/0223-5234(96)88266-3

4. Schio, L.; Chatreaux, F.; Klich, M. Tetrahedron Lett. 2000, 41, 1543-1547. https://doi.org/10.1016/S0040-4039(99)02351-5

5. Hwu, J. R.; Lin, S. Y.; Tsay, S. C.; De, C. E.; Leyssen, P.; Neyts, J. J. Med. Chem. 2011, 54, 2114-2126. https://pubs.acs.org/doi/abs/10.1021/jm101337v

6. Sashidhara, K. V.; Kumar, A.; Chatterjee, M.; Rao, K. B.; Singh, S.; Verma, A. K.; Palit, G. Bioorg. Med. Chem. Lett. 2011, 21, 1937-1941.

https://doi.org/10.1016/i.bmcl.2011.02.040

7. Bansal, Y.; Sethi, P.; Bansal, G. Med. Chem. Res. 2013, 22, 3049-3060. https://link.springer.com/article/10.1007\%2Fs00044-012-0321-6

8. Kostova, I.; Bhatia, S.; Grigorov, P.; Balkansky, S.; Parmar, V. S.; Prasad, A. K. Curr. Med. Chem. 2011, 18, 3929-3951.

http://www.eurekaselect.com/74870/article

9. Ostrov, D. A.; Hernandez, P. J. A.; Corsino, P. E.; Finton, K. A.; Le, N.; Rowe, T. Chemother. 2007, 51, 36883698.

http://aac.asm.org/content/51/10/3688.full.pdf+html

10. Kavitha, K.; Aparna, P. RJLBPCS. 2018, 4, 204-224. http://www.rilbpcs.com/article-pdf-downloads/2018/18/219.pdf 
11. Burguete, A.; Pontiki, E.; Hadjipavlou, L. D.; Ancizu, S.; Villar, R.; Solano, B.; Moreno, E; Torres, E.; Perez, S.; Aldana, I.; Monge, A. Chem. Biol. Drug. Des. 2011, 77, 255-267.

https://doi.org/10.1111/i.1747-0285.2011.01076

12. Seitz, L. E.; Suling, W. J.; Reynolds, R. C. J. Med. Chem. 2002, 45, 5604-5606. https://pubs.acs.org/doi/abs/10.1021/jm020310n

13. Guillon, J.; Forfar, I.; Mamani, M. M.; Desplat, V.; Saliege, M.; Thiolat, D.; Massip, S.; Tabourier, A.; Leger, J. M.; Dufaure, B.; Haumont, G.; Jarrya, C.; Mossalay, D. Bioorg. Med. Chem. 2007, 15, 194-210. https://doi.org/10.1016/i.bmc.2006.09.068

14. Tandon, V. K.; Yadav, B. D.; Maurya, H. K.; Chaturvedi, A. K.; Shukla, P. K. Bioorg. Med. Chem. 2006, 14, 6120-6126.

https://doi.org/10.1016/i.bmc. 2006.04.029

15. Zarranz, B.; Jaso, A.; Aldana, I.; Monge, A. Bioorg. Med. Chem. 2004, 12, 3711-3721. https://doi.org/10.1016/i.bmc.2004.04.013

16. Waring, M. J.; Ben, H. T.; Kotchevar, A. T.; Ramdani, A.; Touzani. R.; Elkadiri, S.; Hakkou, A.; Bouakka, M.; Ellis, T. Molecules 2002, 7, 641-656. https://pdfs.semanticscholar.org/5951/fa5e845e784592c4e5e675fe73c64d6f1d04.pdf

17. Vicente, E.; Lima, L. M.; Bongard, E.; Charnaud, S.; Villar, R.; Solano, B.; Burguete, A.; Perez, S. S.; Aldana, I.; Vivas, L.; Monge, A. Eur. J. Med. Chem. 2008, 43, 1903-1910.

https://doi.org/10.1016/j.ejmech.2007.11.024

18. Kim, Y. B.; Kim, Y. H.; Park, J. Y.; Kim, S. K. Bioorg. Med. Chem. 2004, 14, 541-544. https://doi.org/10.1016/j.bmcl.2003.09.086

19. Jampilek, J. Curr. Med. Chem. 2014, 21, 4347-73. http://www.eurekaselect.com/125230/article

20. Toshima, K.; Takano, K.; Ozawa, T. Chem. Commun. 2002, 212-213. http://pubs.rsc.org/en/content/articlelanding/2002/cc/b107829c\#!divAbstract

21. Sonawane, N. D.; Rangnekar, D. Heterocycl. Chem. 2002, 39, 303-308. https://doi.org/10.1002/ihet.5570390210

22. Katoh, A.; Yoshida, T. Heterocycles 2000, 52, 911-920. https://heterocycles.jp/newlibrary/payments/form/07767/PDF

23. Zhou, J. F.; Gong, G. X.; An, L. T.; Liu, Y.; Zhu, Y. X.; Zhu, Y. L. Synlett 2008, 20, 3163-3166. https://www.thieme-connect.com/products/ejournals/abstract/10.1055/s-0028-1087280

24. Atulkumar, A. K.; Ravindra, R. K.; Mahadev, N. K.; Gireesh, T. Med. Chem. Res. 2016, 25, 1163-1174. https://link.springer.com/article/10.1007/s00044-016-1558-2

25. Kavala, V.; Naik, S.; Patel, B. K. J. Org. Chem. 2005, 70, 4267-4271. https://pubs.acs.org/doi/abs/10.1021/jo050059u

26. Kumar, A.; Alimenla, B.; Jamir, L.; Sinha, D.; Sinha, U. B. Org. Commun. 2012, 5, 64-69 http://www.acgpubs.org/OC/2012/Volume\%205/Issue\%201/8-OC-1111-221.pdf

27. Bora, U.; Chaudhuri, M. K.; Dey, D.; Dhar, S. S. Pure Appl. Chem. 2001, 73, 93-102. https://doi.org/10.1351/pac200173010093

28. Hazarika, S.; Gogoi, P.; Barman, P. RSC Adv. 2015, 5, 25765-25767. http://pubs.rsc.org/en/content/articlelanding/2015/ra/c5ra00677e\#!divAbstract

29. Yujiro, H. Chem. Sci. 2016, 7, 866-880. http://pubs.rsc.org/en/content/articlelanding/2016/sc/c5sc02913a\#!divAbstract 